\title{
Intercellular adhesion molecule-2 is involved in apical ectoplasmic specialization dynamics during spermatogenesis in the rat
}

\author{
Xiang Xiao, C Yan Cheng and Dolores D Mruk \\ Center for Biomedical Research, Population Council, 1230 York Avenue, New York, New York 10065, USA
}

Correspondence

should be addressed to

D D Mruk

Email

mruk@popcbr.rockefeller.edu

\begin{abstract}
In this study, we investigated the role of intercellular adhesion molecule-2 (ICAM2) in the testis. ICAM2 is a cell adhesion protein having important roles in cell migration, especially during inflammation when leukocytes cross the endothelium. Herein, we showed ICAM2 to be expressed by germ and Sertoli cells in the rat testis. When a monospecific antibody was used for immunolocalization experiments, ICAM2 was found to surround the heads of elongating/elongated spermatids in all stages of the seminiferous epithelial cycle. To determine whether ICAM2 is a constituent of apical ectoplasmic specialization (ES), co-immunoprecipitation and dual immunofluorescence staining were performed. Interestingly, ICAM2 was found to associate with $\beta 1$-integrin, nectin-3, afadin, Src, proline-rich tyrosine kinase 2 , annexin II, and actin. Following $\mathrm{CdCl}_{2}$ treatment, ICAM2 was found to be upregulated during restructuring of the seminiferous epithelium, with round spermatids becoming increasingly immunoreactive for ICAM2 by $6-16 \mathrm{~h}$. Interestingly, there was a loss in the binding of ICAM2 to actin during $\mathrm{CdCl}_{2}$-induced germ cell loss, suggesting that a loss of ICAM2-actin interactions might have facilitated junction restructuring. Taken collectively, these results illustrate that ICAM2 plays an important role in apical ES dynamics during spermatogenesis.
\end{abstract}

Key Words

- cell junction

\section{Introduction}

Spermatogenesis is a complex process that culminates in the production and release of step 19 spermatids in the rat, and it involves germ cell development, germ cell adhesion, and germ cell migration (de Kretser \& Kerr 1988, O'Donnell et al. 2006, 2011). Previous studies from this and other laboratories have described many proteins and signaling cascades that are critical for many aspects of spermatogenesis (Vigodner 2011, Walker 2011, Yeh et al. 2011, Cheng \& Mruk 2012). For instance, Sertoli-germ cell adhesion is known to be facilitated by several members of the cadherin superfamily, including both classical and desmosomal cadherins (Goossens \& van Roy 2005, Lie et al. 2011). Intercellular adhesion molecules (ICAMs) comprise another superfamily of adhesion and signaling proteins expressed by different cell types (i.e. endothelial and epithelial cells, platelets, lymphocytes, and monocytes) that are known to mediate homo- and heterophilic interactions. Of these, ICAM2 is a well-studied protein possessing an extracellular domain, a transmembrane domain, and a cytoplasmic 
domain (Staunton et al. 1989). Initially described as a receptor for lymphocyte function-associated antigen-1 (LFA1, a $\beta_{2}$ integrin), ICAM2 is known to be critical for cell adhesion and cell movement. Indeed, its loss disrupted leukocyte transmigration in vitro and in vivo (Gerwin et al. 1999, Huang et al. 2006, Porter \& Hall 2009). Other studies have shown ICAM2 to associate with the actin cytoskeleton by binding various proteins such as $\alpha$-actinin (Heiska et al. 1996), ezrin (Helander et al. 1996), radixin (Hamada et al. 2001), and moesin (Yonemura et al. 1998). Interestingly, ICAM2 clustering was found to trigger tyrosine phosphorylation of ezrin, thereby recruiting phosphoinositide 3-kinase (PI3-K) to the plasma membrane and activating the PI3-K/AKT pathway (Perez et al. 2002), which is known to regulate cell proliferation and cell survival (Datta et al. 1999, Foukas et al. 2010). ICAM2 loss was also found to increase apoptosis in endothelial cells cultured in the absence of serum or in the presence of Fas antibody or staurosporine (Huang et al. 2005). Taken collectively, these results illustrate that ICAM2 is a multifunctional protein. Presently, it is not entirely clear whether ICAM2 plays a role in spermatogenesis. A previous study using Sertoli cells isolated from mouse testes has reported ICAM2 to be undetectable under basal conditions and uninducible by cytokines (i.e. interleukin-1, tumor necrosis factor $\alpha$, and interferon $\gamma$ ) or lipopolysaccharide when assessed by flow cytometry (Riccioli et al. 1995). Also, Icam2 expression was undetectable in 2- and 10 -week mouse testes when examined by RT-PCR (Wakayama et al. 2009). Herein, we re-examine the presence of ICAM2 in the rat testis, and we describe three key findings. First, we report that Icam2 is expressed by germ and Sertoli cells, localizing to contact sites between elongating/elongated spermatids and Sertoli cells (i.e. the apical ectoplasmic specialization (ES)). The apical ES is a testis-specific anchoring junction whose function is constituted by several proteins, many of which are normally found within the focal contact such as $\alpha 6 \beta 1$ integrin, phosphorylated focal adhesion kinase (FAK), and vinculin (Grove et al. 1990, Palombi et al. 1992, Siu et al. 2003). Secondly, administration of $\mathrm{CdCl}_{2}$, an environmental toxicant, was found to disrupt apical ES-mediated adhesion and increase the steadystate level of ICAM2 in adult rats. Finally, ICAM2 was shown to bind actin in the control testis, an association that was abolished following $\mathrm{CdCl}_{2}$ treatment. Taken collectively, these results illustrate that ICAM2 plays an important role at the apical ES in the seminiferous epithelium of the rat testis.

\section{Materials and methods}

\section{Animals}

Male Sprague Dawley rats (adults at 300-325 g b.w.; pups at 10-35 days of age) were purchased from Charles River Laboratories (Kingston, NY, USA). Guidelines issued by the Institutional Animal Care and Use Committee of The Rockefeller University were strictly followed throughout this study (protocol numbers 09-016 and 12-506).

\section{Treatment of rats with $\mathrm{CdCl}_{2}$}

$\mathrm{CdCl}_{2}$ was used to induce the sloughing of germ cells from the seminiferous epithelium (Setchell \& Waites 1970, Wong et al. 2004, Siu et al. 2009b, Elkin et al. 2010). In brief, rats (300-325 g b.w.; $n=3-6$ animals per time point) received a single dose of $\mathrm{CdCl}_{2}(3 \mathrm{mg} / \mathrm{kg}$ b.w., prepared in $0.89 \% \mathrm{NaCl}(\mathrm{w} / \mathrm{v}))$ by i.p. injection. Control rats $(n=3-6)$ were left untreated (Grima \& Cheng 2000, Wong et al. 2004). Upon completion of this experiment, $\mathrm{CdCl}_{2}$ treated animals were treated as biohazard waste and disposed of as directed by The Rockefeller University. The use of $\mathrm{CdCl}_{2}$ was covered by both protocol numbers listed above.

\section{Isolation and culture of testicular cells}

Seminiferous tubules were isolated from adult rat testes by an enzymatic approach using $0.05 \%$ collagenase $(\mathrm{w} / \mathrm{v})$ in DMEM/F-12 (Sigma-Aldrich; Zwain \& Cheng 1994). Seminiferous tubules were pelleted at $700 \boldsymbol{g}$, sonicated in lysis buffer, cleared by centrifugation, and stored at $-80{ }^{\circ} \mathrm{C}$ until used. Sertoli cells were isolated from testes of 20-day-old rats (Cheng et al. 1986, Mruk et al. 2003) and cultured in DMEM/F-12 containing $10 \mu \mathrm{g} / \mathrm{ml}$ insulin, $5 \mu \mathrm{g} / \mathrm{ml}$ human transferrin, $2.5 \mathrm{ng} / \mathrm{ml}$ epidermal growth factor, and $5 \mu \mathrm{g} / \mathrm{ml}$ bacitracin at high density $\left(0.5 \times 10^{6}\right.$ cells $\left./ \mathrm{cm}^{2}\right)$ on Matrigel (BD Biosciences, San Jose, CA, USA)-coated 12-well plates. Sertoli cells were then incubated at $35{ }^{\circ} \mathrm{C}$ in a humidified atmosphere of $95 \%(\mathrm{v} / \mathrm{v})$ air and $5 \% \mathrm{CO}_{2}(\mathrm{v} / \mathrm{v})$. Two days after being isolated, Sertoli cells were treated with a hypotonic buffer

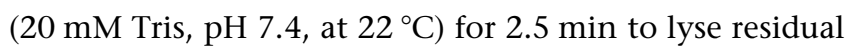
germ cells, yielding Sertoli cells with a purity of $\sim 98 \%$ (Galdieri et al. 1981). Sertoli cells were then cultured for an additional 2 days and subsequently terminated for the extraction of RNA or the preparation of cell lysates. Sertoli cell-conditioned medium (SCCM) was also collected and stored at $-20^{\circ} \mathrm{C}$ until used (Cheng \& Bardin 1987, Mruk et al. 1998). For Sertoli-germ cell cocultures, Sertoli cells

Published by Bioscientifica Ltd 
were seeded at low density $\left(0.05 \times 10^{6}\right.$ cells $\left./ \mathrm{cm}^{2}\right)$ on Matrigel-coated glass coverslips or $100 \mathrm{~mm}$ dishes and cultured as described above. Four days after plating Sertoli cells, germ cells were isolated from 90-day-old rat testes by a mechanical procedure using sequential filtrations through nylon filters of decreasing pore size (Aravindan et al. 1996) and added onto the Sertoli cell epithelium at a Sertoli:germ cell ratio of $\sim 1: 3$. Cocultures were maintained for up to 2 days in order to facilitate the assembly of stable Sertoli-germ cell junctions in DMEM/ F-12 supplemented with $6 \mathrm{mM}$ sodium lactate, $2 \mathrm{mM}$ sodium pyruvate, and the aforementioned factors. Thereafter, cocultures were processed for immunoblotting or immunofluorescence staining. The first time point (i.e. $0 \mathrm{~h}$ ) was obtained by harvesting Sertoli cells in lysis buffer (10 mM Tris, $0.15 \mathrm{M} \mathrm{NaCl}, 1 \% \mathrm{NP}-40(\mathrm{v} / \mathrm{v})$, and $10 \%$ glycerol $(\mathrm{v} / \mathrm{v}), \mathrm{pH} 7.4$, at $22^{\circ} \mathrm{C}$ containing protease and phosphatase inhibitor cocktails at a 1:100 dilution; SigmaAldrich) and immediately combining Sertoli cells with freshly isolated germ cells so that the ratio of Sertoli:germ cells was $\sim 1: 3$. The control consisted of culturing Sertoli cells alone without the addition of germ cells.

\section{RT-PCR}

Total RNA was extracted with TRIzol reagent (Invitrogen) by following the manufacturer's instructions. RT-PCR was performed as described earlier (Xiao et al. 2011). The primer pairs (Gene Link, Hawthorne, NY, USA) used for the amplification of Icam2 (GenBank accession number NM_001007725) and S16 (GenBank accession number X17665) were as follows: 5'-TTACTTTGCCATTTCACTTGTTCG-3' (Icam2 sense, nucleotides 665-688), 5'-CCATCTGGTTGTCTTGCCTTATTT-3' (Icam2 antisense, nucleotides 1047-1070), 5'-TCCGCTGCAGTCCGTTCAAGTCTT-3' (S16 sense, nucleotides 67-90), and 5'-GCCAAACTTCTTGGATTCGCAGCG-3' (S16 antisense, nucleotides 428-451). PCR was conducted with an initial denaturation at $95^{\circ} \mathrm{C}$ for $2 \mathrm{~min}$, followed by 30 cycles with the following parameters: denaturation at $95^{\circ} \mathrm{C}$ for $1 \mathrm{~min}$, annealing at $55.9^{\circ} \mathrm{C}$ for $1 \mathrm{~min}$, and extension at $72^{\circ} \mathrm{C}$ for $1 \mathrm{~min}$. A final extension step at $72^{\circ} \mathrm{C}$ for 5 min was also incorporated into PCR cycling conditions. The authenticity of the Icam2 PCR product was verified by Sanger DNA sequencing (GENEWIZ, South Plainfield, NJ, USA).

Table 1 Antibodies used in this report

\begin{tabular}{|c|c|c|c|c|}
\hline Antibody & Host species & Vendor & Catalog number & Application(s)/dilution(s) \\
\hline \multirow[t]{2}{*}{ ICAM2 } & Rabbit & Santa Cruz Biotechnology & sc-7933 & $\begin{array}{l}\text { IB }(1: 200), \text { IF }(1: 100) \text {, } \\
\text { IHC }(1: 100), \text { IP }(2 \mu \mathrm{g})\end{array}$ \\
\hline & Goat & Santa Cruz Biotechnology & sc-31049 & IF $(1: 100)$ \\
\hline Actin & Goat & Santa Cruz Biotechnology & sc-1616 & IB $(1: 200)$ \\
\hline Testin & Rabbit & Cheng Lab (Cheng et al. 1989) & & IB $(1: 200)$ \\
\hline Occludin & Rabbit & Invitrogen & $71-1500$ & IB $(1: 250)$ \\
\hline $\mathrm{N}$-Cadherin & Rabbit & Santa Cruz Biotechnology & sc-7939 & IB $(1: 200)$ \\
\hline \multirow[t]{2}{*}{ Nectin-3 } & Rabbit & Santa Cruz Biotechnology & sc-28637 & IB $(1: 200)$ \\
\hline & Goat & Santa Cruz Biotechnology & sc-14806 & IF $(1: 50)$ \\
\hline Afadin & Rabbit & Sigma-Aldrich & A0349 & IB (1:500) \\
\hline$\beta 1$-Integrin & Rabbit & Santa Cruz Biotechnology & sc-8978 & IB (1:300), IF (1:100) \\
\hline Laminin $\gamma 3$ & Rabbit & Cheng Lab (Yan \& Cheng 2006) & & IB $(1: 100)$ \\
\hline Src & Mouse & Santa Cruz Biotechnology & sc-8056 & IB (1:200) \\
\hline FAK & Rabbit & Millipore & $06-543$ & IB $(1: 1000)$ \\
\hline Pyk2 & Rabbit & Santa Cruz Biotechnology & sc-9019 & IB $(1: 200)$ \\
\hline Annexin II & Rabbit & Santa Cruz Biotechnology & sc-9061 & IB $(1: 200)$ \\
\hline$\alpha$-Tubulin & Mouse & Santa Cruz Biotechnology & sc-5286 & IB $(1: 200)$ \\
\hline ICAM1 & Rabbit & Novus Biologicals & NB100-81977 & IB $(1: 500)$ \\
\hline Claudin-11 & Rabbit & Invitrogen & $36-4500$ & IB $(1: 250)$ \\
\hline JAM-A & Rabbit & Invitrogen & $36-1700$ & IB $(1: 300)$ \\
\hline CAR & Rabbit & Santa Cruz Biotechnology & sc-15405 & IB $(1: 200)$ \\
\hline$\beta$-Catenin & Rabbit & Invitrogen & $71-2700$ & IB $(1: 250)$ \\
\hline$\alpha 6$-Integrin & Mouse & Santa Cruz Biotechnology & sc-59970 & IB $(1: 300)$ \\
\hline Desmoglein-2 & Rabbit & Santa Cruz Biotechnology & sc-20115 & IB $(1: 200)$ \\
\hline Desmocollin-3 & Rabbit & Santa Cruz Biotechnology & sc-48751 & IB $(1: 200)$ \\
\hline Connexin 43 & Rabbit & Cell Signaling Technology & 3512 & IB (1:200) \\
\hline p-FAK-Y397 & Rabbit & Invitrogen & $44-625 G$ & IB $(1: 1000)$ \\
\hline p-FAK-Y576 & Rabbit & Millipore & 07-157 & IB $(1: 1000)$ \\
\hline p-Src-Y419 & Mouse & Millipore & $05-677$ & IB $(1: 1000)$ \\
\hline p-Src-Y530 & Rabbit & Abcam & ab4817 & IB (1:1000) \\
\hline
\end{tabular}

IB, immunoblotting; IF, immunofluorescence; IHC, immunohistochemistry; IP, immunoprecipitation.

http://www.joe.endocrinology-journals.org DOI: 10.1530/JOE-12-0434
C 2013 Society for Endocrinology Printed in Great Britain
Published by Bioscientifica Ltd 


\section{Co-immunoprecipitation and immunoblotting}

Testis, seminiferous tubule, and Sertoli and germ cell lysates were prepared in lysis buffer. For each reaction, $\sim 800 \mu \mathrm{g}$ protein was incubated with $2 \mu \mathrm{g}$ anti-ICAM2 IgG (Table 1), and co-immunoprecipitation (co-IP) was performed as described previously (Xiao et al. 2011). Thereafter, immunoprecipitated proteins were separated by SDS-PAGE and transferred onto a nitrocellulose membrane for immunoblotting (Table 1). Proteins were visualized by ECL (Mruk \& Cheng 2011a), and images were captured with a Fujifilm LAS-4000 mini imaging system as earlier described (Xiao et al. 2011). Saturated images were not included in the final statistical analysis.

\section{Immunohistochemistry and immunofluorescence staining}

Seven micrometer-thick frozen cross sections were obtained from adult rat testes, mounted onto poly-L-lysinecoated microscope slides (Polysciences, Warrington, PA, USA), and fixed in either Bouin's fixative or $4 \%$ paraformaldehyde $(\mathrm{w} / \mathrm{v})$ in $\mathrm{PBS}\left(10 \mathrm{mM} \mathrm{NaH} \mathrm{PO}_{4}, 0.15 \mathrm{M}\right.$ $\mathrm{NaCl}, \mathrm{pH} 7.4$, at $22^{\circ} \mathrm{C}$ ) as described previously (Xiao et al. 2011). Immunohistochemistry was performed on frozen sections using the SuperPicTure Polymer Detection kit (Invitrogen) and by following the manufacturer's instructions (Table 1). Sections were permeabilized with $0.1 \%$ Triton-X100 (v/v), blocked with 10\% normal donkey serum (v/v) in PBS, and incubated with primary antibody (Table 1). The color reaction was developed using 3-amino-9-ethylcarbazole, which yielded a brownish immunoreactive signal. Immunofluorescence staining was performed on frozen sections as described previously (Xiao et al. 2011). An Alexa Fluor 555 secondary antibody (donkey anti-rabbit IgG; Invitrogen) was used to detect ICAM2, and an Alexa Fluor 488 secondary antibody (donkey anti-goat IgG; Invitrogen) was used to detect $\beta 1$-integrin and nectin-3. All sections processed for immunofluorescence staining were mounted with ProLong Gold antifade reagent containing 4',6-diamidino-2-phenylindole (DAPI, Invitrogen). Images were captured with an Olympus BX61 microscope and MicroSuite Five software (V1224; Olympus America, Melville, NY, USA). Images were analyzed with Photoshop CS3 Extended software (Adobe Systems).

\section{General methods}

Protein concentration was determined using a $\mathrm{D}_{C}$ protein assay kit (Bio-Rad Laboratories) and microplate reader (model 680, Bio-Rad Laboratories) with BSA as a standard.
F-actin was stained using frozen testis cross sections as described previously (Sarkar et al. 2008, Kopera et al. 2009, Mruk \& Lau 2009).

\section{Statistical analyses}

All experiments were conducted in triplicate, and each experiment was repeated at least three times. Statistical analyses were performed with GB-STAT software (V7.0, Dynamic Microsystems, Silver Spring, MD, USA). $P<0.05$ was taken as statistically significant.

\section{Results}

\section{Level of ICAM2 during testis development and its expression by germ and Sertoli cells}

To set the stage for this study, the steady-state level of ICAM2 was examined in developing testes by immunoblotting (Fig. 1A). When data points were individually compared against the level of ICAM2 in the 10-day postnatal testis, significant decreases were noted from 12 to 90 days of age (Fig. 1B). Thereafter, Icam2 expression in the adult rat testis ( 90 days of age) and germ and Sertoli cells was examined by RT-PCR (Fig. 1C) and immunoblotting (Fig. 1D and Table 1). By both methods, ICAM2 was present in the adult testis, germ (isolated from 90-dayold testes and harvested immediately), and Sertoli (isolated from 20-day-old testes and cultured for 4 days) cells. The purity of germ cells was assessed by immunoblotting to determine whether these cells were immunoreactive for testin, a Sertoli and Leydig cell protein (Cheng et al. 1989, Zong et al. 1992). Testin was present in testis and Sertoli cell lysates, as well as in SCCM, but not in germ cell lysate as previously reported (Fig. 1D; Cheng et al. 1989, Zong et al. 1992). This illustrated that germ cell isolations were of negligible Sertoli and Leydig cell contamination. Based on these results, Icam2 expression was higher in Sertoli vs germ cells (Fig. 1E). We emphasize that cells were isolated from testes at two different developmental stages. The reason for this is that it is difficult to isolate highly pure Sertoli cells (relative purity $\sim 85 \%$ ) from the adult rat testis (Li et al. 2001, Anway et al. 2003, Lui et al. 2003), and it is equally difficult to isolate highly pure germ cells from 20-day-old testes. Nevertheless, Sertoli cells isolated from 20-day-old testes were included in this analysis because they had ceased to divide and were differentiated (Orth 1982). They also mimicked Sertoli cells isolated from adult rat testes both morphologically and functionally (Li et al. 2001, Lui et al. 2003).

Published by Bioscientifica Ltd 
We also emphasize that freshly isolated germ cells were used in this analysis. This is because germ cell viability cannot be extended in culture. Next, the localization of ICAM2 was investigated in the adult testis. ICAM2 localized largely to sites adjacent to elongating spermatids (Fig. 1F). In early and late stages of the seminiferous epithelial cycle, ICAM2 staining was diffuse, surrounding both concave and convex sides of spermatid heads.
A

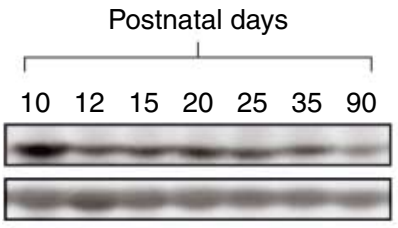

ICAM2, $55 \mathrm{kDa}$

Actin, $42 \mathrm{kDa}$

C

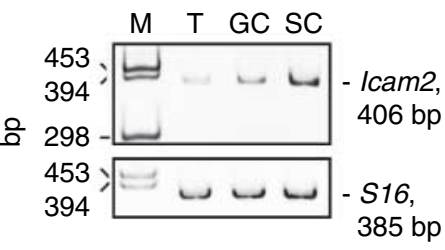

D

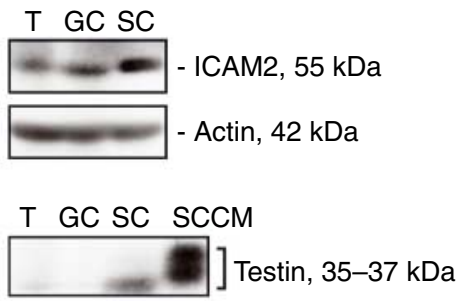

F
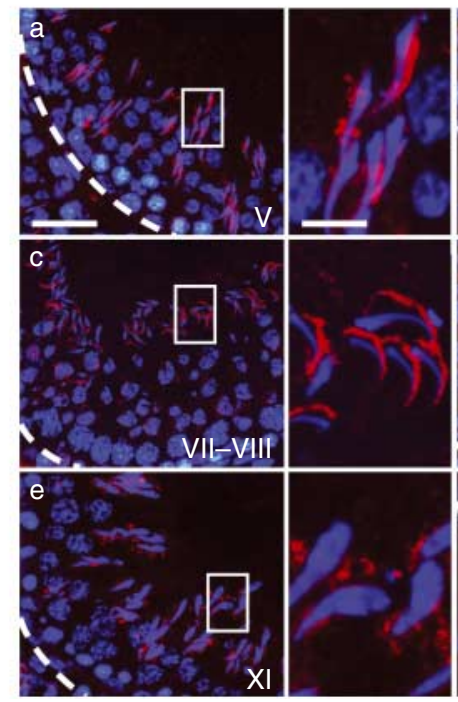
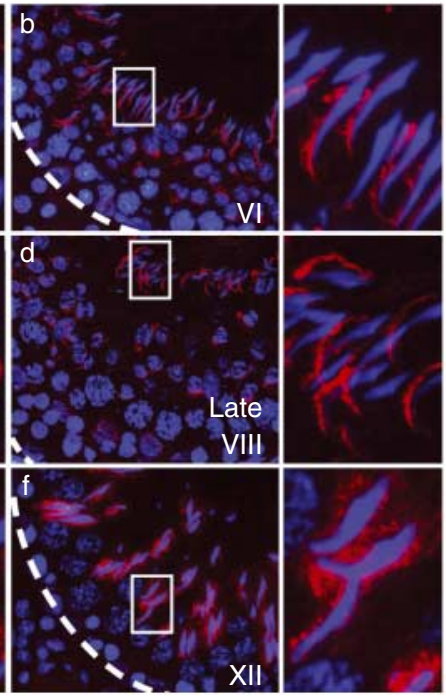

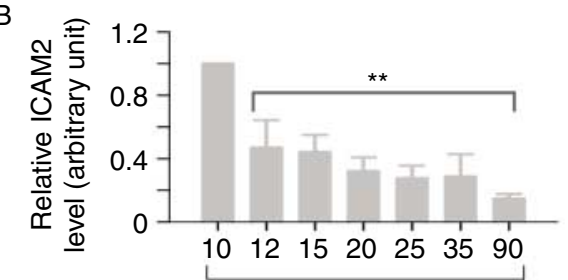

Postnatal days

E
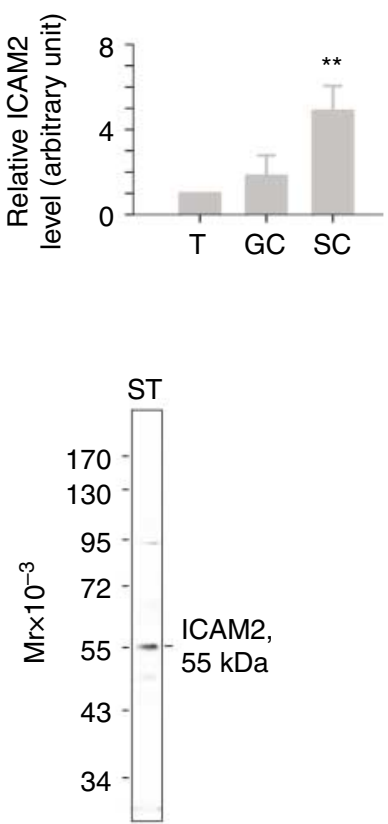

\section{Figure 1}

Steady-state ICAM2 level decreases in the developing rat testis and its presence in germ and Sertoli cells. Lysates obtained from 10-, 12-, 15-, 20-, 25-, 35-, and 90-day-old testes were used for immunoblotting experiments (A, $\sim 50 \mu \mathrm{g}$ protein/lane). Actin was used as an internal control. Histogram (B) summarizing immunoblotting results. Each ICAM2 data point was normalized against its corresponding actin data point and then against 'postnatal day 10 ' which was arbitrarily set at 1 . Each bar represents mean \pm s.D. of three independent experiments. $* * P<0.01$ (Student's $t$-test). RT-PCR (C) and immunoblotting ( $D, \sim 50 \mu \mathrm{g}$ protein/lane) experiments showing ICAM2 in the 90-day-old testis (T), germ (GC), and Sertoli cells (SC). S16 and actin were used as internal controls. Germ cell purity was assessed using testin as a marker for an immunoblotting experiment (D). SCCM was used as a positive control. Histogram (E) summarizing immunoblotting results. Each ICAM2 data point was normalized against its corresponding actin data point and then against 'testis', which was arbitrarily set at 1 . Each bar represents mean \pm s.D. of at least three independent experiments. $* \star P<0.01$ (Student's $t$-test). M, DNA molecular weight marker VI (Roche). Immunofluorescence staining was performed on $7 \mu \mathrm{m}$-thick frozen testis cross sections with anti-ICAM2 IgG (F, Table 1). Boxed areas ( $F, a, b, c, d, e$, and $f$ ) correspond to magnified images that are shown to the right of each low magnification image. Dashed lines ( $F, a, b, c, d$, e, and $f$ ) mark the periphery of seminiferous tubules. Stages of the seminiferous epithelial cycle are denoted as Roman numerals (F). DAPI was used to visualize nuclei $(F, a, b, c, d$, e, and f). $\operatorname{Bar}(F$, a; also applies to b, $c$, $d$, e, and $f)=40 \mu \mathrm{m}$; bar $(F$, first upper left inset; also applies to all other insets) $=10 \mu \mathrm{m}$. An immunoblotting experiment showing the monospecificity of the ICAM2 antibody in seminiferous tubule (ST, $\sim 100 \mu \mathrm{g}$ protein) lysate $(F$, far-right panel). Full colour version of this figure available via http://dx.doi.org/10.1530/JOE-12-0434.

Published by Bioscientifica Ltd. 
At some stages such as at stages XI and XII, ICAM2 was far removed from the proximity of the spermatid head, illustrating that ICAM2 was present within Sertoli cells. Before spermiation, however, ICAM2 staining was very discrete, concentrating largely to the convex side of spermatid heads (Fig. 1F). A weak ICAM2 immunoreactive signal was also found to associate with round spermatids in some stages, but no immunoreactive signal was found at the blood-testis barrier (BTB) whose function is constituted by tight junctions (TJs), basal ESs, desmosomes, and gap junctions (GJs; Mruk \& Cheng 2010, Cheng \& Mruk 2012). Finally, the monospecificity of
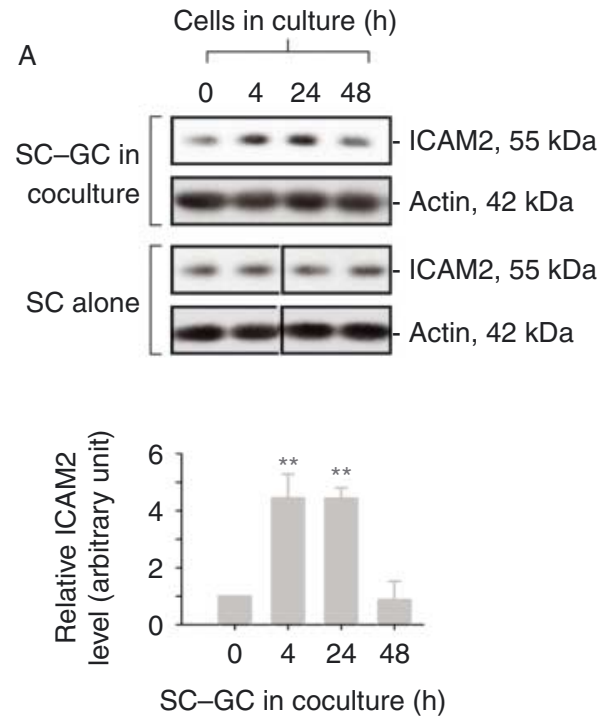

B

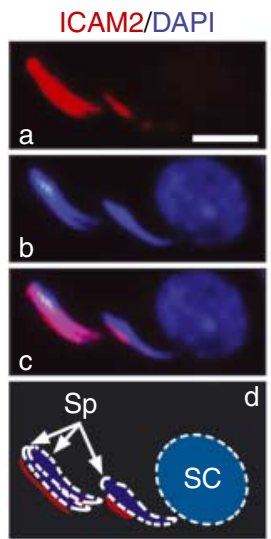

D
C

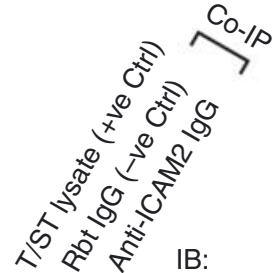

BTB

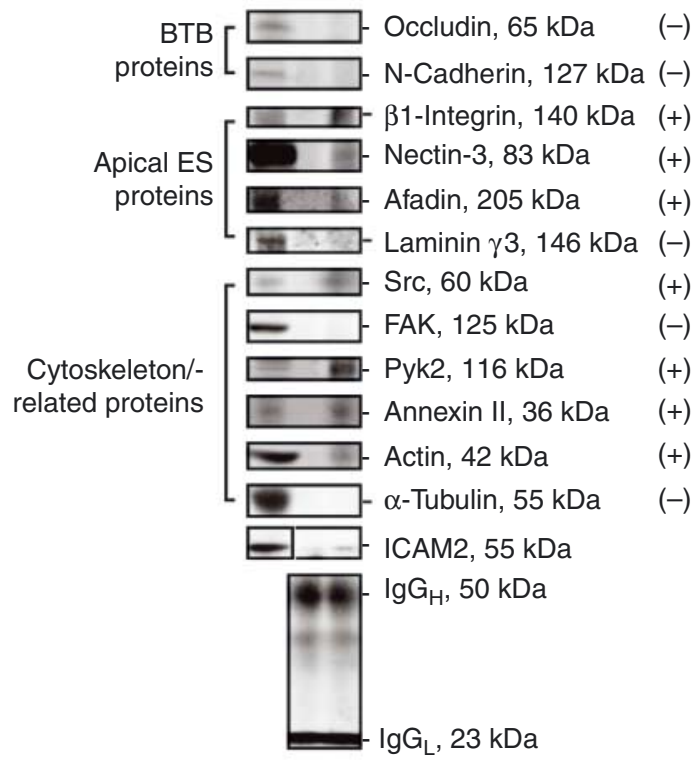

IB:

$(-)$

$(-)$

$(+)$

$(+)$

$(+)$

$(-)$

$(+)$

$(-)$

$(+)$

$(+)$

$(+)$

$(-)$
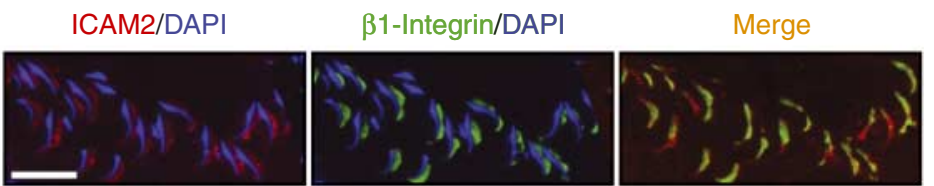

Figure 2

ICAM2 is a constituent protein of the apical ES. Sertoli-germ cell cocultures were terminated at different time points, and lysates were used for immunoblotting experiments ( $A$, upper panel). The control consisted of culturing Sertoli cells alone without the addition of germ cells

(A, bottom of top panel). Actin was used as an internal control. Histogram (A, bottom panel) summarizing immunoblotting results from Sertoli-germ cell cocultures. Each ICAM2 data point was normalized against its corresponding actin data point and then against ' $0 \mathrm{~h}$ ', which was arbitrarily set at 1 . Each bar represents mean \pm s.D. of three independent experiments. $* * P<0.01$ (Student's $t$-test). Immunofluorescence staining was performed using Sertoli-germ cell cocultures ( $B, a, b$, and $c)$. Schematic illustration $(B, d)$ summarizing results. Bar (B, a; also applies to $b$ and $C)=10 \mu \mathrm{m}$. SC, Sertoli cell; Sp, spermatid. Co-IP and immunoblotting (IB) experiments showing structural interactions with ICAM2 when testis
(T) or seminiferous tubule (ST) lysate and anti-ICAM2 IgG were used (C, Table 1). For the positive control (+ve Ctrl), T or ST lysate was used for immunoblotting only. For the negative control (-ve Ctrl), rabbit IgG was used in place of anti-ICAM2 IgG. + , positive co-IP result; - , negative co-IP result. IgG heavy $\left(\operatorname{IgG}_{\mathrm{H}}, 50 \mathrm{kDa}\right)$ and light $\left(\operatorname{lgG}_{\mathrm{L}}, 23 \mathrm{kDa}\right)$ chains served as indicators of equal protein processing. The ability of anti-ICAM2 IgG to pull down interacting proteins was confirmed using anti-ICAM2 IgG for both co-IP and immunoblotting. Dual immunofluorescence staining was performed on $7 \mu \mathrm{m}$-thick frozen testis cross sections with anti-ICAM2 and anti- $\beta 1$-integrin IgGs (D, Table 1). DAPI was used to visualize nuclei (D). Bar (D, far-left panel; also applies to middle and far-right panels) $=20 \mu \mathrm{m}$. Full colour version of this figure available via http://dx.doi.org/10.1530/JOE-12-0434. http://www.joe.endocrinology-journals.org DOI: 10.1530/JOE-12-0434
C 2013 Society for Endocrinology Printed in Great Britain 
the ICAM2 antibody was assessed by immunoblotting (Fig. 1F, right). A predominant $55 \mathrm{kDa}$ protein was observed in seminiferous tubule lysate by SDS-PAGE, and these results are in agreement with the previously published reports on human and murine ICAM2 (Nortamo et al. 1991, Xu et al. 1996).

\section{ICAM2 is a constituent protein of the apical ES, co-immunoprecipitating and co-localizing with $\beta 1$-integrin, nectin-3, and F-actin}

Sertoli-germ cell cocultures were subsequently used for immunoblotting (Fig. 2A) and immunofluorescence staining (Fig. 2B). When compared with Sertoli cells cultured alone, the steady-state level of ICAM2 increased 4-24 $\mathrm{h}$ after the addition of germ cells to Sertoli cells (Fig. 2A), and its localization concentrated to the convex side of spermatid heads (Fig. 2B). These data, together with Fig. 1, suggested that ICAM2 may be a constituent protein of the apical ES, which is the only anchoring device present between elongating/elongated spermatids and Sertoli cells (Russell 1977, Mruk \& Cheng 2004, Vogl et al. 2008). To investigate this, co-IP experiments were performed to determine whether ICAM2 interacts structurally with apical ES proteins (Fig. 2C). ICAM2 was shown to associate with $\beta 1$-integrin, nectin-3, and afadin but not with laminin $\gamma 3$ (apical ES proteins). In addition, ICAM2 did not associate with occludin (a TJ protein) and N-cadherin (a basal ES protein), and these results are in agreement with the lack of ICAM2 immunoreactivity at the BTB (Fig. 1). These experiments also showed ICAM2 to associate with Src and prolinerich tyrosine kinase 2 (Pyk2), nonreceptor tyrosine kinases (Fig. 2C). Moreover, previous studies have shown ICAM2 to associate with several actin-binding proteins (Heiska et al. 1996, 1998, Yonemura et al. 1998, Yoon et al. 2008). Here, we showed ICAM2 to interact with annexin II and actin (Fig. 2C). Annexin II is a $\mathrm{Ca}^{2+}$. dependent phospholipid binding protein with functions in membrane stabilization, junction dynamics, and cytoskeletal organization (Gerke \& Moss 2002). IgG heavy and light chains served as indicators of equal protein processing. The association of ICAM2 with $\beta 1$-integrin was confirmed by dual immunofluorescence staining when these two proteins co-localized to the convex side of spermatid heads during stage VII of the seminiferous epithelial cycle (Fig. 2D).

To corroborate results shown in Figs 1 and 2, ICAM2 was also co-stained with either nectin-3 or F-actin (Fig. 3). Nectin-3 is a $\mathrm{Ca}^{2+}$-independent immunoglobulinlike molecule that facilitates apical ES-based adhesion. It is expressed by elongating/elongated spermatids where
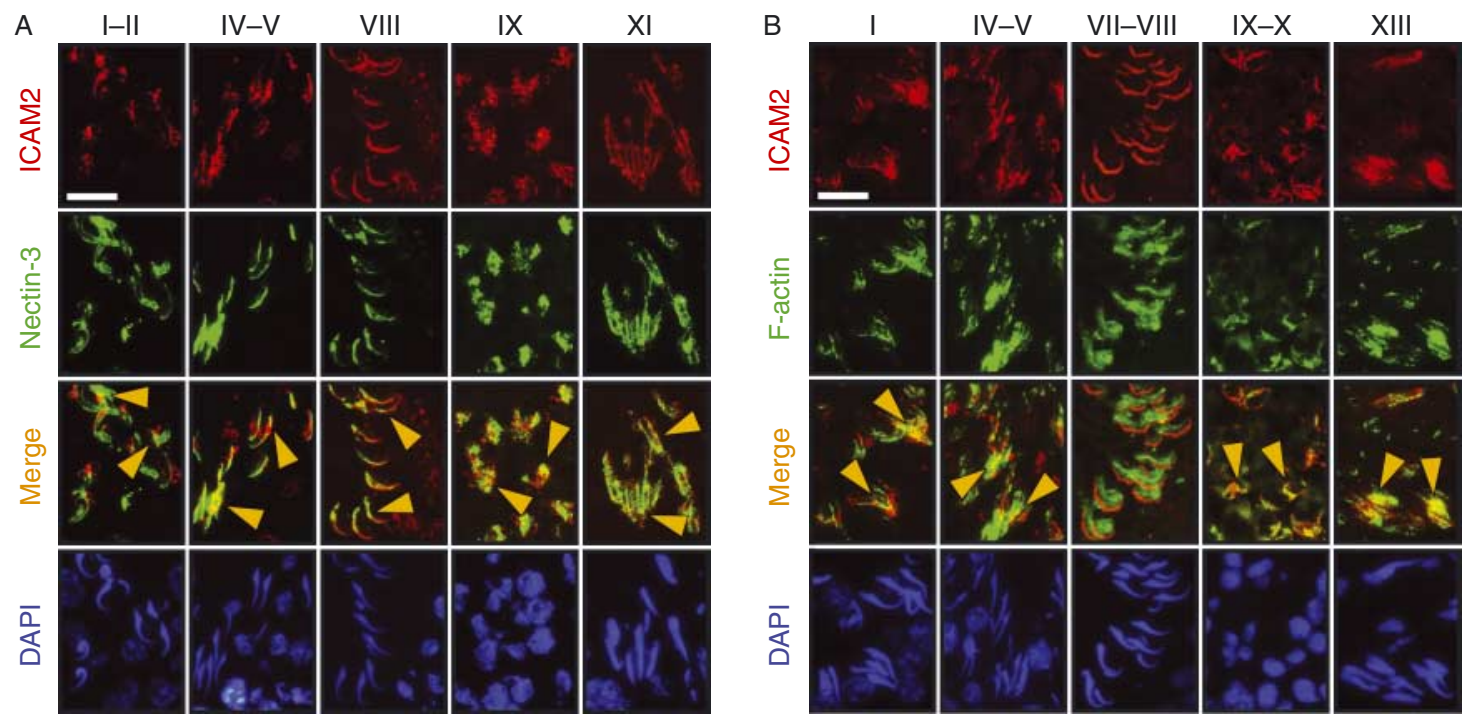

\section{Figure 3}

ICAM2 co-localizes with nectin-3 and F-actin in the seminiferous epithelium of the rat testis. Dual immunofluorescence staining was performed on $7 \mu \mathrm{m}$-thick frozen testis cross sections with anti-ICAM2 and anti-nectin-3 IgGs (A) or with anti-ICAM2 IgG and Oregon Green 488 phalloidin (B). Orange arrowheads point to areas of co-localization ( $A$ and $B$ ).

http://www.joe.endocrinology-journals.org DOI: $10.1530 / J O E-12-0434$
(C) 2013 Society for Endocrinology Printed in Great Britain
Stages of the seminiferous epithelial cycle are denoted as Roman numerals ( $A$ and $B$ ). DAPI was used to visualize nuclei ( $A$ and $B$ ). Bar (A, upper left panel; also applies to all other panels) $=20 \mu \mathrm{m}$; bar (B, upper left panel; also applies to all other panels) $=20 \mu \mathrm{m}$. Full colour version of this figure available via http://dx.doi.org/10.1530/JOE-12-0434.

Published by Bioscientifica Ltd. 
A

Time after administration

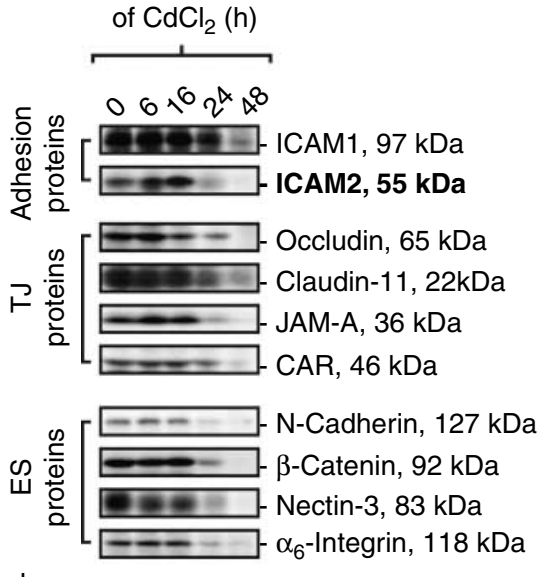

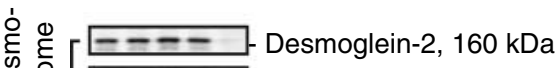

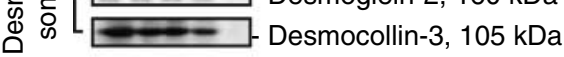

రి - Connexin $43,43 \mathrm{kDa}$
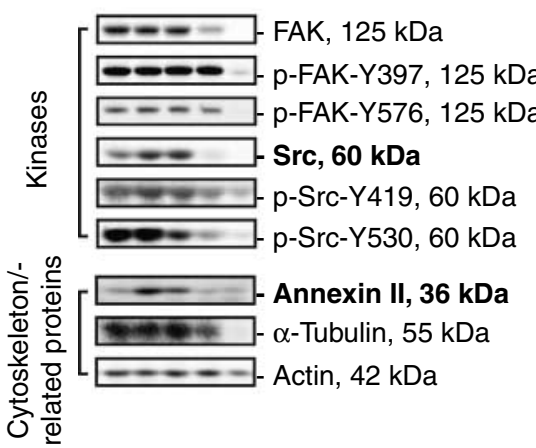

B

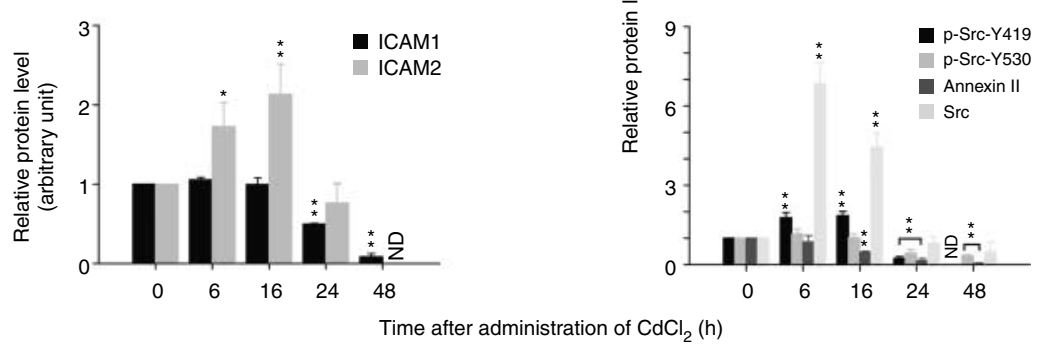

\section{Figure 4}

ICAM2, Src, and annexin II increase during $\mathrm{CdCl}_{2}$-induced testis damage. Immunoblotting experiments showing changes in the levels of several proteins (A). Proteins whose levels increased following $\mathrm{CdCl}_{2}$ treatment are labeled as bold. Actin was used as an internal control. Histograms (B)

it associates heterotypically with Sertoli cell nectin-2 (Ozaki-Kuroda et al. 2002). Interestingly, ICAM2 was shown to co-localize partially with nectin-3 in spermatids (Fig. 3A). However, there were more areas where co-localization between ICAM2 and nectin-3 was not evident, and this staining likely corresponded to the presence of ICAM2 within Sertoli cells. ICAM2 also summarizing immunoblotting results. Each data point was normalized against its corresponding actin data point and then against ' $0 \mathrm{~h}$ ', which was arbitrarily set at 1 . Each bar represents mean \pm s.D. of $n=3-6$ rats. ${ }^{*} P<0.05$; $* * P<0.01$ (Student's $t$-test). ND, not detected

co-localized partially with F-actin throughout the seminiferous epithelial cycle, except at stages VII and VIII when red (ICAM2) and green (F-actin) signals did not merge into an orange sigal (Fig. 3B). DAPI was used to assist in the staging of seminiferous tubules. Taken collectively, these data demonstrate that ICAM2 is an apical ES protein. 


\section{ICAM2 is upregulated during $\mathrm{CdCl}_{2}$-induced germ cell loss}

Previous studies have shown $\mathrm{CdCl}_{2}$ to induce germ cell sloughing from the seminiferous epithelium, as well as BTB disruption (Setchell \& Waites 1970, Wong et al. 2004, Siu et al. 2009b, Elkin et al. 2010). Moreover, there was evidence of interstitial edema and hemorrhage, as well as testicular weight loss, necrosis, atrophy, and calcification (Chiquone 1964, Zielinska-Psuja et al. 1976, Selypes et al. 1992). Following i.p. injection of a single dose of $\mathrm{CdCl}_{2}$ to adult rats, immunoblotting was used to examine the levels of several proteins that are representative of TJ, ES, desmosome, and GJ function (Fig. 4). Interestingly, the levels of only three proteins increased within 6-16 h of $\mathrm{CdCl}_{2}$ treatment, which coincided with germ cell sloughing from the seminiferous epithelium. These proteins were ICAM2, annexin II, and Src with annexin II exhibiting the highest fold changes. The levels of virtually all proteins decreased by $48 \mathrm{~h}$, including the levels of ICAM2, annexin II, and Src (Fig. 4). In this regard, it is worth noting that many of these proteins are expressed by both Sertoli and germ cells. Thus, their downregulation at $48 \mathrm{~h}$ when testes were devoid of most germ cells may be

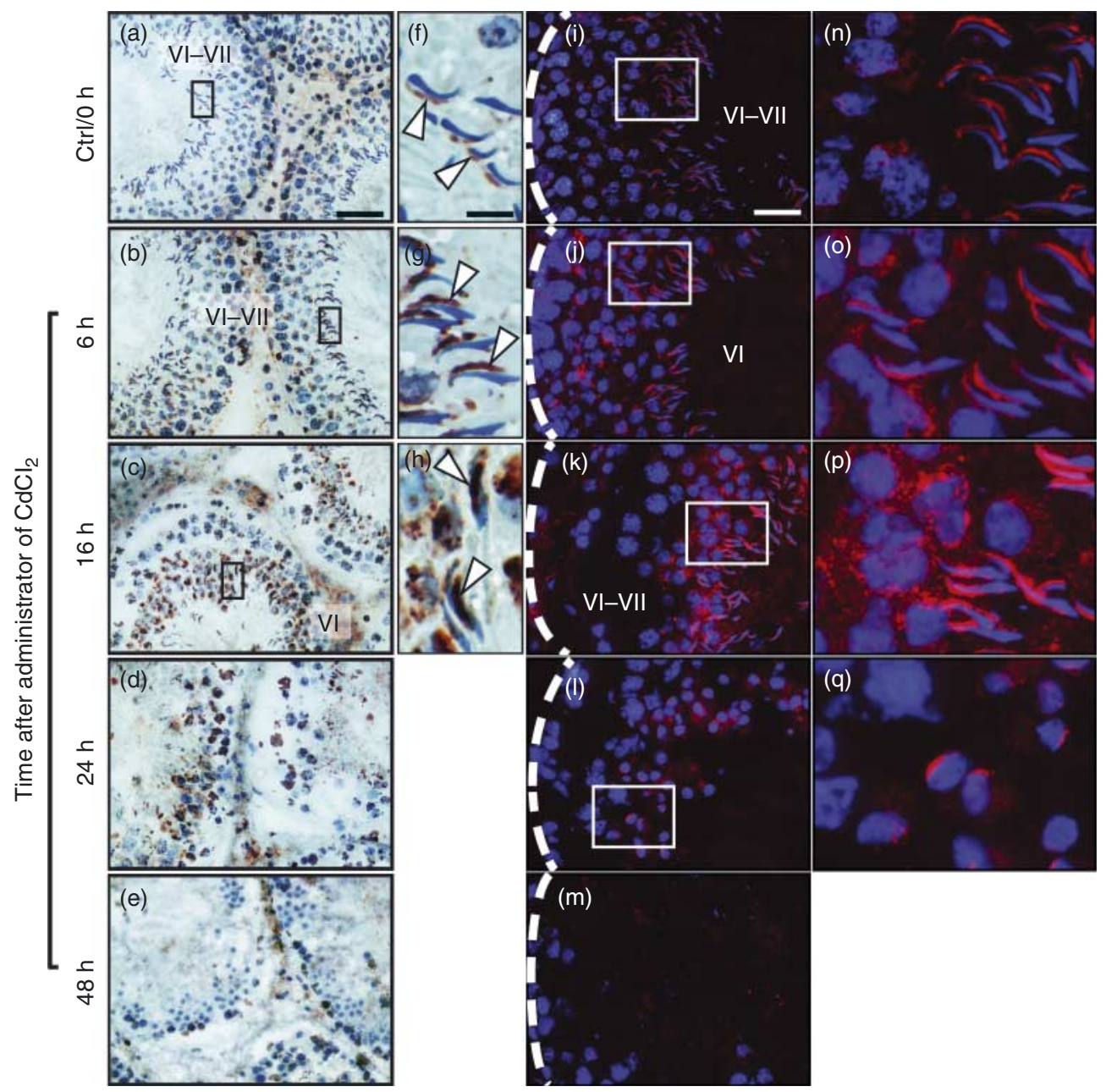

\section{Figure 5}

ICAM2 is upregulated in germ cells following $\mathrm{CdCl}_{2}$ treatment. Immunohistochemistry $(a, b, c, d, e, f, g$, and $h)$ and immunofluorescence staining $(i, j, k, l, m, n, o, p$, and q) were performed on $7 \mu \mathrm{m}$-thick frozen testis cross sections obtained from control (Ctrl) and $\mathrm{CdCl}_{2}$-treated rats with antiICAM2 IgG. Boxed areas ( $a, b, c, i, j, k$, and I) correspond to magnified images that are shown to the right of each low magnification image. White arrowheads ( $f, g$, and $h$ ) point to immunoreactive ICAM2 at the apical ES.
Dashed lines (i, j, k, l, and $m$ ) mark the periphery of seminiferous tubules. Stages of the seminiferous epithelial cycle are denoted as Roman numerals $(a, b, c, i, j$, and $k)$. DAPI was used to visualize nuclei ( $i, j, k, l, m, n, o, p$, and $q$ ). $\operatorname{Bar}(a$, also applies to b, c, d, and e) $=70 \mu \mathrm{m}$; bar (f, also applies to g, h, n, o, p, and $q)=10 \mu \mathrm{m}$; bar $(\mathrm{i}$, also applies to $j, \mathrm{k}, \mathrm{l}$, and $\mathrm{m})=40 \mu \mathrm{m}$. Full colour version of this figure available via http://dx.doi.org/10.1530/JOE-12-0434. http://www.joe.endocrinology-journals.org DOI: $10.1530 / J O E-12-0434$ (c) 2013 Society for Endocrinology Printed in Great Britain
Published by Bioscientifica Ltd 
the result of changes in cell-to-cell ratios within the seminiferous epithelium.

Because ICAM2 was one of the few proteins to increase following administration of $\mathrm{CdCl}_{2}$, its localization was investigated in testes from treated and untreated rats. The goal of this experiment was to determine whether there were any changes in the localization of ICAM2 during $\mathrm{CdCl}_{2}$-induced restructuring of the seminiferous epithelium. In line with the results shown in Fig. 1, ICAM2 localized to elongating/elongated spermatids in the untreated testis (Fig. 5). However, an increase in immunoreactive ICAM 2 was noted by $6-16 \mathrm{~h}$ of $\mathrm{CdCl}_{2}$ treatment. It is also worth noting that round spermatids became increasingly immunoreactive for ICAM 2 by $6-16 \mathrm{~h}$ of $\mathrm{CdCl}_{2}$ treatment when compared with the untreated testis, which may have contributed to the increase in ICAM2 detected by immunoblotting (Fig. 4). By $24-48 \mathrm{~h}$, the seminiferous epithelium was depleted of most germ cells, and ICAM2 immunoreactivity was nearly lost (Fig. 5).

A

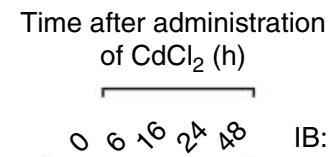

Co-IP: anti-ICAM2 IgG: - Actin, 42 kDa

T Iysate, IB only: Actin, $42 \mathrm{kDa}$

B

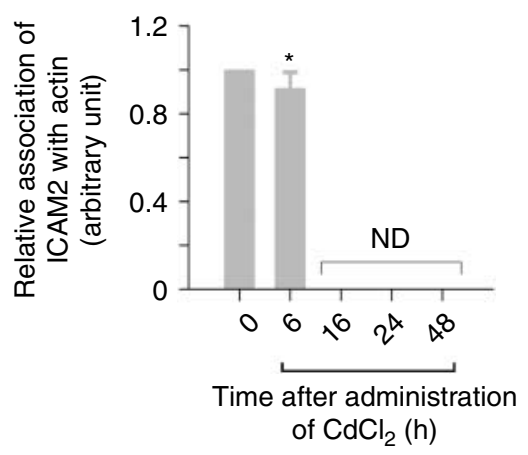

Figure 6

$\mathrm{CdCl}_{2}$-induced testis restructuring disrupts ICAM2-actin interactions. For co-IP experiments (A), $\sim 800 \mu \mathrm{g}$ testis $(\mathrm{T})$ lysate from $\mathrm{CdCl}_{2}$-untreated and treated rats was incubated with anti-ICAM2 IgG, followed by immunoblotting (IB) with an actin antibody (Table 1). Actin was used as an internal control. Histogram (B) summarizing co-IP and immunoblotting results. The relative association of ICAM2 with actin at $0 \mathrm{~h}$ was arbitrarily set at 1 . Each bar represents mean \pm s.D. of three independent experiments. $* P<0.01$ (Student's $t$-test). ND, not detected.

\section{$\mathrm{CdCl}_{2}$-induced restructuring of the seminiferous epithelium results in the loss of ICAM2-actin interactions}

As shown in Fig. 3B, ICAM2 co-localized partially with F-actin at the apical ES throughout the seminiferous epithelial cycle, except at stages VII and VIII when red (ICAM2) and green (F-actin) signals did not merge into an orange signal. These results suggested that dissociation of ICAM2 from actin may be critical for the restructuring of cell junctions and for the subsequent release of spermatozoa at spermiation. As $\mathrm{CdCl}_{2}$ is known to trigger germ cell sloughing from the seminiferous epithelium, we aimed to assess ICAM2-actin interactions with this model as well. Interestingly, there was a loss in the binding of ICAM2 to actin by $16-48 \mathrm{~h}$ when anti-ICAM 2 IgG was used for co-IP (Fig. 6). These results are significant because the steadystate level of ICAM2 increased following $\mathrm{CdCl}_{2}$ treatment (Fig. 4), illustrating that the loss in protein-protein interactions was not likely the result of changes in cellcell ratios.

\section{Discussion}

In this study, we describe three key findings. First, we report that germ and Sertoli cells expressed Icam2 and that ICAM2 localized to elongating/elongated spermatid and Sertoli cell contact sites known as the apical ES, a testis-specific cell junction (Fig. 7). Based on co-IP and immunofluorescence results, ICAM2 was concluded not to be a constituent protein of the BTB. Secondly, we report that ICAM2 was upregulated following administration of $\mathrm{CdCl}_{2}$ and that round spermatids became increasingly immunoreactive for ICAM2 during restructuring of the seminiferous epithelium. Finally, we report that $\mathrm{CdCl}_{2}$-induced restructuring of the seminiferous epithelium involved a loss of ICAM2-actin interactions. Based on immunofluorescence results, this loss in ICAM2-actin interactions may also facilitate spermiation in the normal testis. Previous studies using other in vitro and in vivo models have shown ICAM2, an integral membrane protein, to play an important role in cell adhesion and cell movement (Li et al. 1993, Woodfin et al. 2009). In the seminiferous epithelium, ICAM 2 staining surrounded the heads of elongating/elongated spermatids. Before spermiation, however, ICAM2 staining became very discrete, concentrating to the convex side of spermatid heads at the site of the apical ES. While this staining pattern may be related to the adhesion of germ cells to Sertoli cells, it may also be related to the restructuring of the apical ES, which occurs before

Published by Bioscientifica Ltd. 


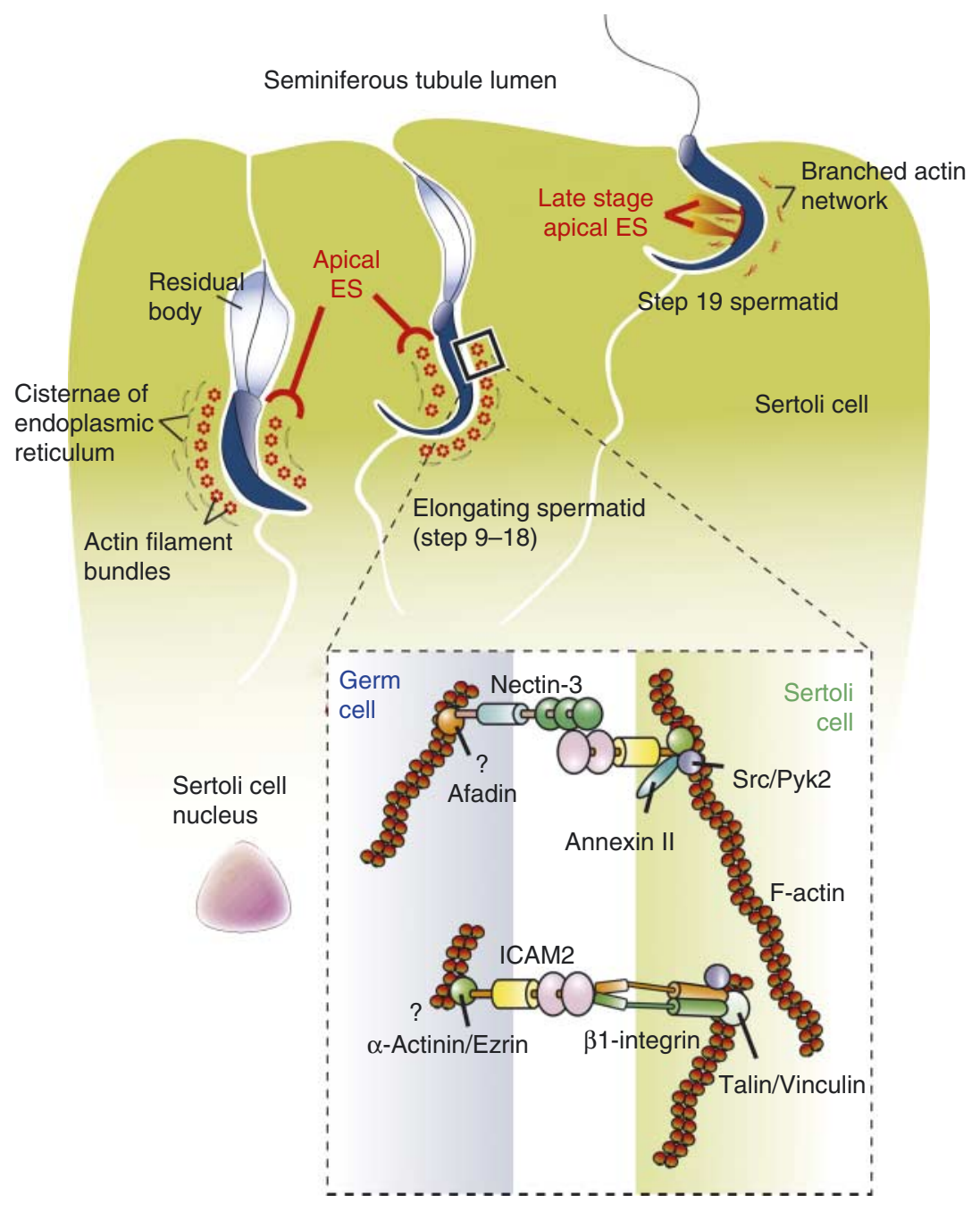

\section{Figure 7}

Schematic illustration summarizing ICAM2 interactions at the apical ES in the seminiferous epithelium of the rat testis. During spermatogenesis, elongating/elongated spermatids (blue) remain attached to Sertoli cells (green) via apical ESs. The apical ES is a tripartite adhesive structure composed of many structural (e.g. $\beta 1$-integrin, nectin-3), scaffolding (e.g. afadin), and signaling (e.g. Src) proteins, supported by bundles of F-actin and outlined by cisternae of endoplasmic reticulum. Based on co-IP and/or dual immunofluorescence staining results (Figs 2, 3, and 6), we concluded ICAM2 to be a constituent protein of the apical ES, associating with $\beta 1$-integrin, nectin-3, afadin, Src, Pyk2, annexin II, and actin.

spermiation (Russell 1977, 1993, Russell \& Peterson 1985). These results were corroborated by dual immunofluorescence staining when ICAM2 was found to co-localize partially with $\beta 1$-integrin and nectin-3, as well as with F-actin. In the testis, $\beta 1$-integrin is present both at the apical ES and at the BTB, whereas nectin-3 is present only at the apical ES (Ozaki-Kuroda et al. 2002, Cheng et al. 2011). Furthermore, nectin-3 is expressed only by spermatids (Ozaki-Kuroda et al. 2002, Takai \& Nakanishi 2003).
Moreover, ICAM2 failed to co-localize with F-actin at stages VII and VIII of the seminiferous epithelial cycle (Fig. 3), suggesting that disruption of ICAM2-actin interactions may facilitate restructuring of the apical ES. For the sake of simplicity, we depict within a single dimensional plane three spermatids at different stages of development, although this does not accurately represent the organization of the seminiferous epithelium in vivo. Also, only proteins interacting with ICAM2 are shown in this schematic illustration; other apical ES proteins are not shown. Full colour version of this figure available via http://dx.doi.org/10.1530/JOE-12-0434.

Taken together with results from co-IP experiments, which showed ICAM2 to bind $\beta 1$-integrin and nectin-3, ICAM2 appears to function in the adhesion of late-stage spermatids to Sertoli cells, and its role as a cell adhesion protein is in agreement with other studies.

In this study, ICAM2 was also found to bind annexin II. Annexin II, a member of the annexin family of proteins, is known to bind negatively charged phospholipids such as phosphatidylinositol 4,5-bisphosphate found in cellular

Published by Bioscientifica Ltd. 
membranes in a $\mathrm{Ca}^{2+}$-dependent manner (Gerke \& Moss 2002, Gerke et al. 2005). Annexin II has diverse roles in different epithelial and endothelial cells, and it is known to be present in Sertoli cells (Dreier et al. 1998). For instance, it can function in membrane domain stabilization, ion transport, endocytosis, cell proliferation, signal transduction, junction dynamics, and cytoskeletal organization (Gerke \& Moss 2002, Gerke et al. 2005). In each of these $\mathrm{Ca}^{2+}$-regulated processes, annexins are believed to bring together or 'bridge' several cytoplasmic proteins, thereby assembling multi-protein complexes that are required for normal cell function. Thus, the adhesive role of ICAM2 is further supported by its interaction with annexin II. It is possible that annexin II is helping to bridge ICAM2 to actin-binding proteins such as ezrin in the control testis. It is also possible that Src is phosphorylating proteins within this protein complex as annexin II is known to be a substrate of $\mathrm{v}$-Src (Haynes \& Moss 2009). This may result in clustering of ICAM 2 and in additional changes in protein-protein interactions, thereby triggering signaling cascades that control cell adhesion and cell movement in the testis.

Herein, we show that ICAM2 was upregulated and that ICAM2 associated strongly with round spermatids following administration of $\mathrm{CdCl}_{2}$, an environmental toxicant known to induce germ cell sloughing from the seminiferous epithelium (Setchell \& Waites 1970, Wong et al. 2004, Siu et al. 2009b, Elkin et al. 2010). This in vivo model was used because environmental toxicants can affect spermatogenesis and contribute to subfertility/infertility (Siu et al. 2009a, Mruk \& Cheng 2011b, Lagos-Cabre \& Moreno 2012). Annexin II and Src, which were shown to bind ICAM2, also increased following administration of $\mathrm{CdCl}_{2}$. As annexin II is known to link the cytoskeleton to the plasma membrane and to be involved in membrane dynamics, its role may be to facilitate the displacement of ICAM2 away from the cell surface (i.e. endocytosis) and to contribute to junction restructuring. It is also possible that these three proteins increased because they assemble into a functional multiprotein complex. Nevertheless, ICAM2 may prove to be an excellent marker of testicular dysfunction in future studies because any deviation from its normal expression and/or localization pattern appears to disrupt cell-cell interactions.

Interestingly, ICAM2 did not co-localize with F-actin at stages VI and VII of the seminiferous epithelial cycle, suggesting that dissociation of ICAM2 from actin may be critical for the restructuring of cell junctions and for the subsequent release of spermatozoa at spermiation. These results were corroborated when testis lysates were used from $\mathrm{CdCl}_{2}$-treated rats for co-IP experiments. This mechanism of junction restructuring may also involve protein endocytosis as ICAM2 would no longer be linked to its scaffold. At this point, it is worth noting that ICAM2 is not the only ICAM expressed by the testis. ICAM1 is also expressed by this organ but its primary role is in BTB dynamics (Xiao et al. 2012). Regardless, ICAM1 was also found to localize to the apical ES, suggesting that it too may be important in Sertoli-spermatid adhesion. While Icam2 null mice were found to be fertile (Gerwin et al. 1999), it is possible that other proteins such as ICAM1 may have compensated for its loss of function or that ICAM2 is simply dispensable for Sertoli-spermatid adhesion. It is also possible that a loss of Icam 2 may not have significantly affected existing protein-protein interactions at the apical ES so that germ cell adhesion and spermatogenesis remained unaffected. Future studies will likely provide further insight on the role of ICAM2 in the testis.

\section{Declaration of interest}

The authors declare that there is no conflict of interest that could be perceived as prejudicing the impartiality of the research reported.

\section{Funding}

This work was supported in part by NICHD, NIH (R03 HD061401 to D D M; R01 HD056034 and U54 HD029990 Project 5 to C Y C).

\section{References}

Anway MD, Folmer J, Wright WW \& Zirkin BR 2003 Isolation of Sertoli cells from adult rat testes: an approach to ex vivo studies of Sertoli cell function. Biology of Reproduction 68 996-1002. (doi:10.1095/biolreprod. 102.008045)

Aravindan GR, Pineau CP, Bardin CW \& Cheng CY 1996 Ability of trypsin in mimicking germ cell factors that affect Sertoli cell secretory function. Journal of Cellular Physiology 168 123-133. (doi:10.1002/(SICI)10974652(199607)168:1 < 123::AID-JCP15>3.0.CO;2-8)

Cheng CY \& Bardin CW 1987 Identification of two testosterone-responsive testicular proteins in Sertoli cell-enriched culture medium whose secretion is suppressed by cells of the intact seminiferous tubule. Journal of Biological Chemistry 262 12768-12779.

Cheng CY \& Mruk DD 2012 The blood-testis barrier and its implication in male contraception. Pharmacological Reviews 64 16-64. (doi:10.1124/pr. 110.002790)

Cheng CY, Mather JP, Byer AL \& Bardin CW 1986 Identification of hormonally responsive proteins in primary Sertoli cell culture medium by anion-exchange high performance liquid chromatography. Endocrinology 118 480-488. (doi:10.1210/endo-118-2-480)

Cheng CY, Grima J, Stahler MS, Lockshin RA \& Bardin CW 1989 Testins are structurally related Sertoli cell proteins whose secretion is tightly coupled to the presence of germ cells. Journal of Biological Chemistry $\mathbf{2 6 4}$ 21386-21393.

Cheng CY, Lie PP, Mok KW, Cheng YH, Wong EW, Mannu J, Mathur PP, Yan HH \& Mruk DD 2011 Interactions of laminin $\beta 3$ fragment with $\beta 1$-integrin receptor: a revisit of the apical ectoplasmic 
specialization-blood-testis-barrier-hemidesmosome functional axis in the testis. Spermatogenesis 1 174-185. (doi:10.4161/spmg.1.3.17076)

Chiquone AD 1964 Observations on the early events of cadmium necrosis in the testis. Anatomical Record 149 23-35. (doi:10.1002/ar. 1091490104)

Datta SR, Brunet A \& Greenberg ME 1999 Cellular survival: a play in three Akts. Genes and Development 13 2905-2927. (doi:10.1101/gad.13.22.2905)

Dreier R, Schmid KW, Gerke V \& Riehmann K 1998 Differential expression of annexins I, II and IV in human tissues: an immunohistochemical study. Histochemistry and Cell Biology 110 137-148. (doi:10.1007/ s004180050275)

Elkin ND, Piner JA \& Sharpe RM 2010 Toxicant-induced leakage of germ cell-specific proteins from seminiferous tubules in the rat: relationship to blood-testis barrier integrity and prospects for biomonitoring. Toxicological Sciences 117 439-448. (doi:10.1093/toxsci/kfq210)

Foukas LC, Berenjeno IM, Gray A, Khwaja A \& Vanhaesebroeck B 2010 Activity of any class IA PI3K isoform can sustain cell proliferation and survival. PNAS 107 11381-11386. (doi:10.1073/pnas.0906461107)

Galdieri M, Ziparo E, Palombi F, Russo M \& Stefanini M 1981 Pure Sertoli cell cultures: a new model for the study of somatic-germ cell interactions. Journal of Andrology 2 249-254.

Gerke V \& Moss SE 2002 Annexins: from structure to function. Physiological Reviews 82 331-371. (doi:10.1152/physrev.00030.2001)

Gerke V, Creutz CE \& Moss SE 2005 Annexins: linking $\mathrm{Ca}^{2+}$ signaling to membrane dynamics. Nature Reviews. Molecular Cell Biology 6 449-461. (doi:10.1038/nrm1661)

Gerwin N, Gonzalo JA, Lloyd C, Coyle AJ, Reiss Y, Banu N, Wang B, Xu H, Avraham H, Engelhardt B et al. 1999 Prolonged eosinophil accumulation in allergic lung interstitium of ICAM-2 deficient mice results in extended hyper-responsiveness. Immunity 10 9-19. (doi:10.1016/ S1074-7613(00)80002-3)

Goossens S \& van Roy F 2005 Cadherin-mediated cell-cell adhesion in the testis. Frontiers in Bioscience 10 398-419. (doi:10.2741/1537)

Grima J \& Cheng CY 2000 Testin induction: the role of cyclic 3',5' adenosine monophosphate/protein kinase A signaling in the regulation of basal and lonidamine-induced testin expression by rat Sertoli cells. Biology of Reproduction 63 1648-1660. (doi:10.1095/ biolreprod63.6.1648)

Grove BD, Pfeiffer DC, Allen S \& Vogl AW 1990 Immunofluorescence localization of vinculin in ectoplasmic ("junctional") specializations of rat Sertoli cells. American Journal of Anatomy 188 44-56. (doi:10.1002/ aja.1001880106)

Hamada K, Shimizu T, Matsui T, Tsukita S \& Hakoshima T 2001 Crystallographic characterization of the radixin FERM domain bound to the cytoplasmic tail of the adhesion protein ICAM-2. Acta Crystallographica. Section D. Biological Crystallography 57 891-892. (doi:10.1107/S0907444901005716)

Haynes MJ \& Moss SE 2009 Annexin 2 has a dual role as regulator and effector of v-Src in cell transformation. Journal of Biological Chemistry 284 10202-10210. (doi:10.1074/jbc.M807043200)

Heiska L, Kantor C, Parr T, Critchley DR, Vilja P, Gahmberg CG \& Carpen O 1996 Binding of the cytoplasmic domain of intercellular adhesion molecule-2 (ICAM-2) to $\alpha$-actinin. Journal of Biological Chemistry 271 26214-26219. (doi:10.1074/jbc.271.42.26214)

Heiska L, Alfthan K, Gronholm M, Vilja P, Vaheri A \& Carpen O 1998 Association of ezrin with intercellular adhesion molecule-1 and -2 (ICAM-1 and ICAM-2). Regulation by phosphatidylinositol 4,5bisphosphate. Journal of Biological Chemistry 273 21893-21900. (doi:10.1074/jbc.273.34.21893)

Helander TS, Carpen O, Turunen O, Kovanen PE, Vaheri A \& Timonen T 1996 ICAM-2 redistributed by ezrin as a target for killer cells. Nature $\mathbf{3 8 2}$ 265-268. (doi:10.1038/382265a0)

Huang MT, Mason JC, Birdsey GM, Amsellem V, Gerwin N, Haskard DO, Ridley AJ \& Randi AM 2005 Endothelial intercellular adhesion molecule (ICAM)-2 regulates angiogenesis. Blood 106 1636-1643. (doi:10.1182/blood-2004-12-4716)
Huang MT, Larbi KY, Scheiermann C, Woodfin A, Gerwin N, Haskard DO \& Nourshargh S 2006 ICAM-2 mediates neutrophil transmigration in vivo: evidence for stimulus specificity and a role in PECAM-1independent transmigration. Blood 107 4721-4727. (doi:10.1182/ blood-2005-11-4683)

Kopera I, Su L, Bilinska B, Cheng CY \& Mruk DD 2009 An in vivo study on adjudin and blood-testis barrier dynamics. Endocrinology 150 4724-4733. (doi:10.1210/en.2008-1779)

de Kretser DM \& Kerr JB 1988 The cytology of the testis. In The Physiology of Reproduction, pp 837-932. Eds E Knobil, JB Neill, LL Ewing, GS Greenwald, CL Markert \& DW Pfaff. New York: Raven Press.

Lagos-Cabre R \& Moreno RD 2012 Contribution of environmental pollutants to male infertility: a working model of germ cell apoptosis induced by plasticizers. Biological Research 45 5-14. (doi:10.4067/ S0716-97602012000100001)

Li R, Nortamo P, Valmu L, Tolvanen M, Huuskonen J, Kantor C \& Gahmberg CG 1993 A peptide from ICAM-2 binds to the leukocyte integrin CD11a/CD18 and inhibits endothelial cell adhesion. Journal of Biological Chemistry 268 17513-17518.

Li JCH, Lee WM, Mruk DD \& Cheng CY 2001 Regulation of Sertoli cell myotubularin (rMTM) expression by germ cells in vitro. Journal of Andrology 22 266-277.

Lie PP, Cheng CY \& Mruk DD 2011 The biology of the desmosome-like junction: a versatile anchoring junction and signal transducer in the seminiferous epithelium. International Review of Cell and Molecular Biology 286 223-269. (doi:10.1016/B978-0-12-385859-7.00005-7)

Lui WY, Lee WM \& Cheng CY 2003 Transforming growth factor- $\beta 3$ regulates the dynamics of Sertoli cell tight junctions via the p38 mitogen-activated protein kinase pathway. Biology of Reproduction 68 1597-1612. (doi:10.1095/biolreprod.102.011387)

Mruk DD \& Cheng CY 2004 Cell-cell interactions at the ectoplasmic specialization in the testis. Trends in Endocrinology and Metabolism 15 439-447. (doi:10.1016/j.tem.2004.09.009)

Mruk DD \& Cheng CY 2010 Tight junctions in the testis: new perspectives. Philosophical Transactions of the Royal Society of London. Series B: Biological Sciences 365 1621-1635. (doi:10.1098/rstb.2010.0010)

Mruk DD \& Cheng CY $2011 a$ Enhanced chemiluminescence (ECL) for routine immunoblotting: an inexpensive alternative to commercially available kits. Spermatogenesis 1 121-122. (doi:10.4161/spmg.1.2. 16606)

Mruk DD \& Cheng CY $2011 b$ Environmental contaminants: is male reproductive health at risk? Spermatogenesis 1 283-290. (doi:10.4161/ spmg.1.4.18328)

Mruk DD \& Lau ASN 2009 RAB13 participates in ectoplasmic specialization dynamics in the rat testis. Biology of Reproduction 80 590-601. (doi:10.1095/biolreprod.108.071647)

Mruk DD, Cheng CH, Cheng YH, Mo MY, Grima J, Silvestrini B, Lee WM \& Cheng CY 1998 Rat testicular extracellular superoxide dismutase: its purification, cellular distribution, and regulation. Biology of Reproduction 59 298-308. (doi:10.1095/biolreprod59.2.298)

Mruk DD, Siu MKY, Conway AM, Lee NPY, Lau ASN \& Cheng CY 2003 Role of tissue inhibitor of metalloproteases- 1 in junction dynamics in the testis. Journal of Andrology 24 510-523.

Nortamo P, Salcedo R, Timonen T, Patarroyo M \& Gahmberg CG 1991 A monoclonal antibody to the human leukocyte adhesion molecule intercellular adhesion molecule-2. Cellular distribution and molecular characterization of the antigen. Journal of Immunology 146 2530-2535.

O'Donnell L, Meachem SI, Stanton PG \& McLachlan RI 2006 Endocrine regulation of spermatogenesis. In Knobil and Neill's Physiology of Reproduction, pp 1017-1069. Ed JD Neill. New York: Elsevier.

O'Donnell L, Nicholls PK, O’Bryan MK, McLachlan RI \& Stanton PG 2011 Spermiation: the process of sperm release. Spermatogenesis 1 14-35 (doi:10.4161/spmg.1.1.14525)

Published by Bioscientifica Ltd. 
Orth JM 1982 Proliferation of Sertoli cells in fetal and postnatal rats: a quantitative autoradiographic study. Anatomical Record 203 485-492. (doi:10.1002/ar.1092030408)

Ozaki-Kuroda K, Nakanishi H, Ohta H, Tanaka H, Kurihara H, Mueller S, Irie K, Ikeda W, Sakai T, Wimmer E et al. 2002 Nectin couples cell-cell adhesion and the actin scaffold at heterotypic testicular junctions. Current Biology 12 1145-1150. (doi:10.1016/S0960-9822(02)00922-3)

Palombi F, Salanova M, Tarone G, Farini D \& Stefanini M 1992 Distribution of $\beta 1$ integrin subunit in rat seminiferous epithelium. Biology of Reproduction 47 1173-1182. (doi:10.1095/biolreprod47.6.1173)

Perez OD, Kinoshita S, Hitoshi Y, Payan DG, Kitamura T, Nolan GP \& Lorens JB 2002 Activation of the PKB/AKT pathway by ICAM-2. Immunity 16 51-65. (doi:10.1016/S1074-7613(02)00266-2)

Porter JC \& Hall A 2009 Epithelial ICAM-1 and ICAM-2 regulate the egression of human T cells across the bronchial epithelium. FASEB Journal 23 492-502. (doi:10.1096/fj.08-115899)

Riccioli A, Filippini A, De Cesaris P, Barbacci E, Stefanini M, Starace G \& Ziparo E 1995 Inflammatory mediators increase surface expression of integrin ligands, adhesion to lymphocytes, and secretion of interleukin 6 in mouse Sertoli cells. PNAS 92 5808-5812. (doi:10.1073/pnas.92.13.5808)

Russell LD 1977 Observations on rat Sertoli ectoplasmic ('junctional') specializations in their association with germ cells of the rat testis. Tissue \& Cell 9 475-498. (doi:10.1016/0040-8166(77)90007-6)

Russell LD 1993 Morphological and functional evidence for Sertoli-germ cell relationships. In The Sertoli Cell, pp 365-390. Eds LD Russell \& MD Griswold. Clearwater: Cache River Press.

Russell LD \& Peterson RN 1985 Sertoli cell junctions: morphological and functional correlates. International Review of Cytology 94 177-211.

Sarkar O, Mathur PP, Cheng CY \& Mruk DD 2008 Interleukin-1 $\alpha$ (IL1A) is a novel regulator of the blood-testis barrier in the rat. Biology of Reproduction 78 445-454. (doi:10.1095/biolreprod.107.064501)

Selypes A, Serenyi P, Boldog I, Bokros F \& Takacs S 1992 Acute and "longterm" genotoxic effects of $\mathrm{CdCl} 2$ on testes of mice. Journal of Toxicology and Environmental Health 36 401-409. (doi:10.1080/ 15287399209531647)

Setchell BP \& Waites GMH 1970 Changes in the permeability of the testicular capillaries and of the "blood-testis barrier" after injection of cadmium chloride in the rat. Journal of Endocrinology 47 81-86. (doi:10.1677/joe.0.0470081)

Siu MKY, Mruk DD, Lee WM \& Cheng CY 2003 Adhering junction dynamics in the testis are regulated by an interplay of $\beta 1$ integrin and focal adhesion complex-associated proteins. Endocrinology 144 2141-2163. (doi:10.1210/en.2002-221035)

Siu ER, Mruk DD, Porto CS \& Cheng CY 2009a Cadmium-induced testicular injury. Toxicology and Applied Pharmacology 238 240-249. (doi:10.1016/ j.taap.2009.01.028)

Siu ER, Wong EWP, Mruk DD, Porto CS \& Cheng CY $2009 b$ Focal adhesion kinase is a blood-testis barrier regulator. PNAS 106 9298-9303. (doi:10.1073/pnas.0813113106)

Staunton DE, Dustin ML \& Springer TA 1989 Functional cloning of ICAM2, a cell adhesion ligand for LFA-1 homologous to ICAM-1. Nature 339 61-64. (doi:10.1038/339061a0)

Takai Y \& Nakanishi H 2003 Nectin and afadin: novel organizers of intercellular junctions. Journal of Cell Science 116 17-27. (doi:10.1242/jcs.00167)

Vigodner M 2011 Roles of small ubiquitin-related modifiers in male reproductive function. International Review of Cell and Molecular Biology 288 227-259. (doi:10.1016/B978-0-12-386041-5.00006-6)
Vogl AW, Vaid KS \& Guttman JA 2008 The Sertoli cell cytoskeleton. In Molecular Mechanisms in Spermatogenesis, pp 186-211. Ed CY Cheng. Austin, TX: Landes Bioscience and Springer Science+Business Media.

Wakayama T, Nakata H, Kurobo M, Sai Y \& Iseki S 2009 Expression, localization, and binding activity of the ezrin/radixin/moesin proteins in the mouse testis. Journal of Histochemistry and Cytochemistry $\mathbf{5 7}$ 351-362. (doi:10.1369/jhc.2008.952440)

Walker WH 2011 Testosterone signaling and the regulation of spermatogenesis. Spermatogenesis 1 116-120. (doi:10.4161/spmg.1.2.16956)

Wong CH, Mruk DD, Lui WY \& Cheng CY 2004 Regulation of blood-testis barrier dynamics: an in vivo study. Journal of Cell Science 117 783-798. (doi:10.1242/jcs.00900)

Woodfin A, Voisin MB, Imhof BA, Dejana E, Engelhardt B \& Nourshargh S 2009 Endothelial cell activation leads to neutrophil transmigration as supported by the sequential roles of ICAM-2, JAM-A, and PECAM-1. Blood 113 6246-6257. (doi:10.1182/blood-2008-11-188375)

Xiao X, Mruk DD, Lee WM \& Cheng CY 2011 c-Yes regulates cell adhesion at the blood-testis barrier and the apical ectoplasmic specialization in the seminiferous epithelium of rat testes. International Journal of Biochemistry \& Cell Biology 43 651-665. (doi:10.1016/j.biocel. 2011.01.008)

Xiao X, Cheng CY \& Mruk DD 2012 Intercellular adhesion molecule-1 is a regulator of blood-testis barrier function. Journal of Cell Science (In press) (doi:10.1242/jcs.107987).

Xu H, Bickford JK, Luther E, Carpenito C, Takei F \& Springer TA 1996 Characterization of murine intercellular adhesion molecule-2. Journal of Immunology 156 4909-4914.

Yan HH \& Cheng CY 2006 Laminin $\alpha 3$ forms a complex with $\beta 3$ and $\gamma 3$ chains that serves as the ligand for $\alpha 6 \beta 1$-integrin at the apical ectoplasmic specialization in adult rat testes. Journal of Biological Chemistry 281 17286-17303. (doi:10.1074/jbc.M513218200)

Yeh JR, Zhang X \& Nagano MC 2011 Wnt5a is a cell-extrinsic factor that supports self-renewal of mouse spermatogonial stem cells. Journal of Cell Science 124 2357-2366. (doi:10.1242/jcs.080903)

Yonemura S, Hirao M, Doi Y, Takahashi N, Kondo T \& Tsukita S 1998 Ezrin/radixin/moesin (ERM) proteins bind to a positively charged amino acid cluster in the juxta-membrane cytoplasmic domain of CD44, CD43 and ICAM-2. Journal of Cell Biology 140 885-895. (doi:10.1083/jcb.140.4.885)

Yoon KJ, Phelps DA, Bush RA, Remack JS, Billups CA \& Khoury JD 2008 ICAM-2 expression mediates a membrane-actin link, confers a nonmetastatic phenotype and reflects favorable tumor stage or histology in neuroblastoma. PLOS ONE 3 e3629. (doi:10.1371/journal. pone.0003629)

Zielinska-Psuja B, Malendowicz LK \& Senczuk W 1976 Studies on the toxic effect of cadmium in the rat. I. Testicular changes induced by a single subcutaneous injection of cadmium chloride. Zeitschrift für Mikroskopisch-Anatomische Forschung 90 1063-1073.

Zong SD, Bardin CW, Phillips D \& Cheng CY 1992 Testins are localized to the junctional complexes of rat Sertoli and epididymal cells. Biology of Reproduction 47 568-572. (doi:10.1095/biolreprod47.4.568)

Zwain IH \& Cheng CY 1994 Rat seminiferous tubular culture medium contains a biological factor that inhibits Leydig cell steroidogenesis: its purification and mechanism of action. Molecular and Cellular Endocrinology 104 213-227. (doi:10.1016/0303-7207(94) 90124-4)

Received in final form 19 October 2012

Accepted 24 October 2012

Accepted Preprint published online 24 October 2012 http://www.joe.endocrinology-journals.org DOI: 10.1530/JOE-12-0434
(C) 2013 Society for Endocrinology Printed in Great Britain
Published by Bioscientifica Ltd 